\section{Hydrocooling as an Alternative to Forced- air Cooling for Maintaining Fresh-market Strawberry Quality}

\author{
Marcos D. Ferreira ${ }^{1}$, Jeffrey K. Brecht ${ }^{2}$, Steven A. Sargent ${ }^{2}$, and \\ Craig K. Chandler ${ }^{3}$
}

AdDitional INDEX wORDs. Fragaria xananassa, plastic film, nutrients

SUMMARY. Hydrocooling was evaluated as an alternative to forced-air cooling for strawberry (Fragaria xananassa) fruit. 'Sweet Charlie' strawberries were cooled by forced-air and hydrocooling to $4^{\circ} \mathrm{C}$ and held in different storage regimes in three different trials. Quality attributes, including surface color, firmness, weight loss, soluble solids, and ascorbic acid content, $\mathrm{pH}$ and total titratable acidity, were evaluated at the full ripe stage. Fruit hydrocooled to $4{ }^{\circ} \mathrm{C}$ and stored at different temperatures for $\mathbf{8}$ or $\mathbf{1 5}$ days showed overall better quality than forcedair cooled fruit, with significant differences in epidermal color, weight loss, and incidence and severity of decay. Fruit stored wrapped in polyvinylchloride (PVC) film after forced-air cooling or hydrocooling retained better color, lost less weight, and retained greater firmness than fruit stored uncovered, but usually had increased decay. There is potential for using hydrocooling as a cooling method for strawberries.

$\mathrm{M}$ ost produce items should be quickly cooled for removal of field heat to an appropriate temperature for successful shipment over long distances (Sargent et al., 1991). Cooling retards metabolism, including respiration, senescence, softening, textural changes, and color changes after harvest for quality retention (Arifin and Chau, 1987). Commodities that have a high rate of metabolism, such as strawberries, should be rapidly cooled after harvest (Talbot and Chau, 1991). The respiration rate of strawberries varies with changes in temperature. At the optimal storage temperature for strawberries of $0{ }^{\circ} \mathrm{C}$, the respiration [i.e., carbon dioxide $\left(\mathrm{CO}_{2}\right)$ production] rate is $12-18$ $\mathrm{mg} \cdot \mathrm{kg}^{-1}$ per hour, while at 25 to $27^{\circ} \mathrm{C}$, a typical pulp temperature at harvest, the respiration rate is more than 10 fold higher [169-211 mg. $\mathrm{kg}^{-1}$ per hour $\mathrm{CO}_{2}$ (Hardenburg et al., 1986)]

Losses of strawberries due to deterioration increase as delays between harvesting and cooling exceed $\mathrm{l} \mathrm{h}$ (Mitcham and Mitchell, 2002), and

${ }^{1}$ Faculdade de Engenharia Agrícola, Universidade Estadual de Campinas, C.P.: 6011, CEP.: 10383-875, Campinas, SP, Brazil; e-mail: marcos.ferreira@agr. unicamp.br

${ }^{2}$ Horticultural Sciences Department, University of Florida, Gainesville, FL 32611-0690.

${ }^{3}$ Gulf Coast Research and Education Center, University of Florida, Balm, FL 33598 losses of about $70 \%$ of the strawberries can occur with field delays of about 8 h (Mitchell et al., 1996). The temperature of harvested strawberries in the field can be $30{ }^{\circ} \mathrm{C}$ or higher when exposed to the sun. If the temperature of a fruit is raised from $0{ }^{\circ} \mathrm{C}$ to $10^{\circ} \mathrm{C}$ its rate of deterioration can increase twoto four-fold. The recommendation for maximum quality of strawberries is cooling to near $0{ }^{\circ} \mathrm{C}$ within $1 \mathrm{~h}$ of harvest (Talbot and Chau, 1991) and maintaining the fruit at $0{ }^{\circ} \mathrm{C}$ throughout the marketing channels (Mitchell et al., 1996). In commercial operations, cooling to this recommended temperature is rarely approached. Usually the strawberries are cooled and shipped at temperatures that range from 2 to $5^{\circ} \mathrm{C}$ (Talbot and Chau, 1991). However, Collins and Perkins-Veazie (1993) reported that strawberry fruit stored at $5{ }^{\circ} \mathrm{C}$ decayed and deteriorated faster than those stored at $1{ }^{\circ} \mathrm{C}$. It has also been reported that a polyethylene wrap can reduce weight loss and keep the fruit in overall better condition (Collins and Perkins-Veazie, 1993).

Forced-air cooling, also known as pressure cooling, provides a high flow rate of cold air through containers of produce by establishing a difference in air pressure on opposite faces of palletized produce, removing field heat. The air is humidified to $90 \%$ relative humidity $(\mathrm{RH})$ or higher to minimize water loss during cooling. Forced-air cooling is the standard method for cooling strawberry.

Hydrocooling removes heat at a faster rate than forced-air cooling. The heat capacity of refrigerated water is much greater than that for air, which means that a given volume of water can remove more heat than the same volume of air at the same temperature (Thompson et al., 2002). A quality benefit from hydrocooling is that it does not remove water from the commodities (Sargent et al., 1991). Use of hydrocooling requires that the commodity be tolerant of direct contact with water and not be sensitive to sanitizing chemicals, such as chlorine (Kays, 1991). Hydrocooling is a common practice for many commodities, such as peaches [Prunus persica (Bennet et al., 1965; Redit et al., 1955)], asparagus [Asparagus officinalis (Lill and Laundon, 1984)], tropical fruits, and root crops.

It has been commonly assumed that strawberries are sensitive to contact with water, causing an increased risk of disease. Therefore, hydrocooling has not been recommended to cool the fruit (Kasmire and Thompson, 1992; Kays, 1991; Mitchell et al., 1996; Talbot and Chau, 1991). However, the assumption that water contact from hydrocooling would have negative

\begin{tabular}{llll}
\hline $\begin{array}{l}\text { Units } \\
\text { To convert U.S. to SI, } \\
\text { multiply by }\end{array}$ & U.S. unit & SI unit & $\begin{array}{l}\text { To convert SI to U.S., } \\
\text { multiply by }\end{array}$ \\
\hline 29.5735 & $\mathrm{fl} \mathrm{oz}$ & $\mathrm{mL}$ & 0.0338 \\
3.7854 & gal & $\mathrm{L}$ & 0.2642 \\
0.7457 & horsepower & $\mathrm{kW}$ & 1.3410 \\
2.54 & inch(es $)$ & $\mathrm{cm}$ & 0.3937 \\
25.4 & inch(es) & $\mathrm{mm}$ & 0.0394 \\
0.4536 & $\mathrm{lb}$ & $\mathrm{kg}$ & 2.2046 \\
4.4482 & $\mathrm{lbf}$ & $\mathrm{N}$ & 0.2248 \\
28.3495 & $\mathrm{oz}$ & $\mathrm{g}$ & 0.0353 \\
1 & $\mathrm{ppm}$ & $\mathrm{mg} \cdot \mathrm{kg}^{-1}$ & 1 \\
1 & $\mathrm{ppm}$ & $\mathrm{mg} \cdot \mathrm{L}^{-1}$ & 1 \\
0.4732 & $\mathrm{pt}$ & $\mathrm{L}$ & 2.1134 \\
$\left({ }^{\circ} \mathrm{F}-32\right) \div 1.8$ & ${ }^{\circ} \mathrm{F}$ & ${ }^{\circ} \mathrm{C}$ & $\left(1.8 \times{ }^{\circ} \mathrm{C}\right)+32$
\end{tabular}


consequences for strawberries is likely based on observations of fruit that were harvested during wet conditions in the field and packed wet since no research has been reported that indicates negative effects of hydrocooling strawberries. Observations related to the propensity of wet-harvested strawberries to develop postharvest fruit rots may not apply to strawberries cooled after harvest to near their optimum storage temperature using cold, chlorinated water (Ferreira et al., 1996). Rose and Gorman (1936) even reported that wetting harvested strawberries with ambient temperature water did not cause decay to develop more rapidly during shipment; the washed strawberries in their experiment showed a gain in weight when compared to air cooled fruit and, when strawberries were wetted before air-cooling, it was observed that the cooling rate was greater. Similarly, Goble and Cooler (1962) reported that hydrocooled strawberries had better quality than non-hydrocooled strawberries; hydrocooled fruit were actually reported to have developed less decay than non-hydrocooled fruit; hydrocooled strawberries had less weight loss or some gain of weight than nonhydrocooled fruit; and hydrocooling did not affect soluble solids content and $\mathrm{pH}$. Overall, sensory panel tests and consumer analyses were favorable to hydrocooling (Goble and Cooler, 1962).

Roa et al. (1977) reported on hydrocooling of strawberries followed by shipping conditions that simulated an export shipment from Argentina to Germany. The strawberries were hydrocooled in water at $3{ }^{\circ} \mathrm{C}$ for 5 min. Fruit that were hydrocooled and wrapped with a PVC film had less weight loss than air cooled and unwrapped fruit, and there was no difference in color between the former fruit and fresh strawberries. Nor were there differences between fruit treated or not with benomyl fungicide, indicating that hydrocooling did not increase decay. Increased use of returnable plastic containers makes hydrocooling of strawberries a potentially feasible commercial operation.

The goal of this research was to evaluate the feasibility of immersion hydrocooling as an alternative to forced-air cooling for strawberries. The quality of fruit from the different cooling methods was compared in terms of color, composition, firmness, and weight loss, and also incidence and severity of decay. Due to the possibility that water contact on hydrocooled strawberry fruit could favor development of decay, the effect of chlorination of the hydrocooling water and use of a water vapor barrier (PVC) film wrap applied after cooling was also evaluated.

\section{Material and methods}

'Sweet Charlie' strawberries were obtained from a commercial farm in Floral City, Fla., in three separate harvests and transported to the laboratory in Gainesville by air-conditioned vehicle within 2 h of harvest. Fruit at the full-ripe stage (completely red) and of uniform size were sorted for freedom from defects. Four plastic mesh 1-pt baskets, each containing 10 fruit, for a total of 40 fruit were used in each treatment. The fruit were conditioned after harvest for $6 \mathrm{~h}$ at $30{ }^{\circ} \mathrm{C}$ and $45 \% \mathrm{RH}$ to simulate typical conditions between harvest and cooling in commercial strawberry handling operations (Nunes et al., 1995 ) prior to $7 / 8$ cooling (i.e., the standard commercial practice of reducing the fruit pulp temperature by $7 / 8$ of the difference between the initial pulp temperature and the cooling medium temperature) by either forcedair cooling or hydrocooling.

Hydrocooling treatments, with or without chlorine $\left(1^{\circ} \mathrm{C}\right.$ water, $200 \mathrm{mg}$ $\mathrm{L}^{-1}$ free chlorine, $\mathrm{pH} 7$ ), were accomplished by immersing 40 fruit. Fruit were in baskets within mesh bags in 15 $\mathrm{L}$ of cold water $\left(1^{\circ} \mathrm{C}\right)$ in an insulated container with $23{ }^{\circ} \mathrm{C}$ surrounding air temperature. Ice was added as needed in order to keep the water temperature at $1{ }^{\circ} \mathrm{C}$ and the water was recirculated at $19 \mathrm{~L} \cdot \mathrm{min}^{-1}$ using a submersible pump (115-V alternating current, 1.7 amps, 1 horsepower; Little Giant Pump Co., Oklahoma City, Okla.). The fruit were removed from the water when the pulp temperature reached $4{ }^{\circ} \mathrm{C}$ (about $6 \mathrm{~min}$ ).

Forced-air cooling was accomplished with a unit previously described by Nunes et al. (1995). Fruit in opentop mesh pint baskets in standard strawberry cartons ( 12 baskets per flat) were forced-air cooled to $4^{\circ} \mathrm{C}$ within $\mathrm{l}$ h in a $1^{\circ} \mathrm{C}$ cold room and $90 \% \mathrm{RH}$. Immediately after cooling, fruit were stored in the baskets with or without being entirely wrapped with a PVC film (W44-75, $0.019 \mathrm{~mm}$ thickness;
RJR Packaging, Winston-Salem, N.C.) used as a water vapor barrier.

The following storage regimes were tested: (1) After cooling, strawberries were stored with or without PVC film wrap for $7 \mathrm{~d}$ at $1^{\circ} \mathrm{C}$, followed by $\mathrm{ld}$ at $20^{\circ} \mathrm{C}$, to simulate retail handling conditions. (2) Cooled strawberries were stored with or without PVC film wrap for $7 \mathrm{~d}$ at $1^{\circ} \mathrm{C}$, followed by $5 \mathrm{~d}$ at $15^{\circ} \mathrm{C}, 2 \mathrm{~d}$ at $7{ }^{\circ} \mathrm{C}$, and $1 \mathrm{~d}$ at 20 ${ }^{\circ} \mathrm{C}$, in order to simulate non-optimal commercial handling during storage/ transport, holding at a distribution center or terminal market, additional holding in a retail store backroom, and finally retail display. (3) Cooled fruit were stored with or without PVC film wrap for $7 \mathrm{~d}$ at $1{ }^{\circ} \mathrm{C}$, followed by $7 \mathrm{~d}$ at $7^{\circ} \mathrm{C}$, plus $1 \mathrm{~d}$ at $20^{\circ} \mathrm{C}$. The PVC film wrap was used as a vapor barrier to delay drying of the water left on fruit from the hydrocooling treatments as well as slow water loss from fruit during storage, thus providing a worst case scenario for potential decay promotion by hydrocooling. Three trials were conducted using fruit from separate harvests: in trial 1 , storage regimes 1 and 2 were applied; and in trials 2 and 3 , storage regimes 1 and 3 were applied. The forced-air cooled fruit were discarded due to excessive decay prior to completion of storage regime 2 in the first trial and thus were not included in the evaluations. Similarly, the extent of decay present at the end of storage regime 3 in the third trial precluded conducting color, firmness, weight loss or composition measurements, so only decay incidence and severity were evaluated.

\section{Nondestructive analyses}

Surface COLOR. Fruit surface color measurements were performed on 40 individual fruit per treatment using a Minolta chroma meter (Minolta Corp., Ramsey, N.J.) after the final storage period in all three trials. The $\operatorname{CIELAB}\left(\mathrm{L}^{*}, \mathrm{a}^{*}, \mathrm{~b}^{*}\right)$ scale and D65 light source were used. The instrument was calibrated using a standard white plate. Color measurements were expressed in terms of $\mathrm{L}^{*}$ value, hue angle $\left(\tan ^{-1} \mathrm{~b} / \mathrm{a}\right)$, and chroma value $\left(a^{2}+b^{2}\right)^{1 / 2}$ (McGuire, 1992; Shewfelt et al., 1988).

WeIGHT LOss. Strawberry baskets (four per treatment) were weighed initially, on the day after hydrocooling, upon each transfer from one storage temperature to another, and after the 
final storage period. The strawberry weight loss (percent) during a particular storage regime was calculated on a fresh weight (FW) basis (difference between initial and final fruit weight) with the weight of the plastic mesh basket subtracted.

DECAY SEVERITY AND INCIDENCE. Incidence and severity of decay on 40 individual fruit per treatment were evaluated after the final storage period in all trials. Decay incidence was recorded by counting individual fruit with the presence of decay. For decay severity, the Horsfall-Barratt scale was used to rate visually the amount of fruit surface area affected by decay: $1=0 \%$ to $1 \% ; 2=1 \%$ to $3 \% ; 3=3 \%$ to $6 \% ; 4$ $=6 \%$ to $12 \% ; 5=12 \%$ to $25 \% ; 7=50 \%$ to $75 \% ; 8=75 \%$ to $88 \%$; $9=88 \%$ to $94 \% ; 10=94 \%$ to $97 \% ; 11=97 \%$ to $99 \% ; 12=99 \%$ to $100 \%$ (Horsfall and Barratt, 1945).

\section{Destructive analyses}

Firmness. Measurements were made on 10 fruit per treatment after storage using an Instron Universal Testing Instrument (model 1132; Instron Corp., Canton, Mass.), with a load cell of $50 \mathrm{~kg}$ and crosshead speed of $10 \mathrm{~cm} \cdot \mathrm{min}^{-1}$. Each fruit was placed on its side and a 16-mm-diameter convex tip probe was used to determine the force (Newtons) required to cause 3-mm deformation.

After firmness measurements, the 10 fruit from each of the four replicates (i.e., baskets) per treatment were blended in a Waring blender to make homogeneous slurries. Each replicate fruit slurry was frozen in a plastic freezer bag at $-25^{\circ} \mathrm{C}$ for later analyses. Upon thawing, each slurry was centrifuged for $20 \mathrm{~min}$ at 5000 $\mathscr{g}_{\mathrm{n}}$ in a refrigerated centrifuge. The decanted, semi-clear juice was strained through cheesecloth and placed in a 50-mL tube, covered with parafilm, and frozen for later analysis of soluble solids content (SSC), total titratable acidity (TTA), and $\mathrm{pH}$.

Soluble solids CONTENT. The SSC was determined by placing one to two drops of the strawberry juice derived from each replicate fruit slurry onto the prism of a Mark II Abbe refractometer (Buffalo, N.Y.) and reading ${ }^{\circ} \mathrm{Brix}$, which was reported as percent SSC.

Total titratable acidity. Six grams of the strawberry juice per replicate were diluted with $50 \mathrm{~mL}$ of distilled water. Each sample was titrated with 0.1 $\mathrm{N}$ sodium hydroxide $(\mathrm{NaOH})$ to a $\mathrm{pH}$ 8.2 endpoint with an automatic titrimeter(Fisher Scientific, Pittsburgh). The milliliters of $0.1 \mathrm{~N} \mathrm{NaOH}$ were used to calculate TTA as follows:

$\%$ acid

$$
=\mathrm{mLNaOH} \times 0.1 \mathrm{~N} \times 0.064 \mathrm{~g} \times
$$
100

$$
6 \mathrm{~g} \text { of juice }
$$

The milliequivalent factor, 0.064 , used in this calculation is for citric acid (FW 192.12), the major acid in strawberry juice.

$\mathrm{pH}$. The $\mathrm{pH}$ of the juice was determined with a $\mathrm{pH}$ meter (Corning Medical and Scientific Instruments, Medfield, Mass.) standardized to $\mathrm{pH}$ 4.0 and $\mathrm{pH} 7.0$.

Ascorbic ACID CONTENT. A portion of each replicate fruit slurry was combined with a mixture of $6 \%$ metaphosphoric acid in $2 \mathrm{~N}$ acetic acid. The fruit slurry was combined with the acid mixture in a ratio of $1 \mathrm{~g}: 10$ $\mathrm{mL}$, and then frozen until used. Upon thawing, the fruit slurry-acid mixture was centrifuged for $20 \mathrm{~min}$ at 5000 $\mathscr{g}_{\mathrm{n}}$ and the supernatant was filtered through Whatman \#l paper before analysis. The filtered supernatant was used to measure ascorbic acid content (AAC) using the dinitrophenylhydrazine method of Terada et al. (1978). The concentrations of total ascorbic acid were calculated as mg per $100 \mathrm{~g}$ tissue fresh weight from absorbance measured at $540 \mathrm{~nm}$ using a standard curve.

\section{Statistical analyses}

The data collected after each storage regime were analyzed in a randomized complete-block design with harvest dates (trials) as blocks. The blocks were analyzed separately since a clear interaction occurred between block and cooling method. The data were subjected to analysis of variance (PROC ANOVA) and the levels of significance of the main effects and interactions determined with the $F$ test. Percentage data were arcsine transformed to stabilize the variance before performing analysis of variance. Orthogonal contrasts were used to compare the means of the forced-air cooling treatments with the means of the two hydrocooling treatments, and also to compare the means of the chlorine treatments with the means of the non-chlorine treatments (Hochberg and Tamhane, 1987). All statistical analyses were completed using SAS for PC software (SAS Institute Inc., Cary, N.C.).

\section{Results}

Application of chlorine in the hydrocooling water had no effect on any of the quality factors measured other than decay. Thus, plus and minus chlorine results in wrapped and unwrapped hydrocooling treatments were averaged for presentation of results for surface color, firmness, weight loss, and fruit composition.

SURFACE COLOR. In the first trial, hydrocooled, wrapped fruit had higher $\mathrm{L}^{*}$, larger hue angle, and higher chroma after storage for $7 \mathrm{~d}$ at $1^{\circ} \mathrm{C}+1 \mathrm{~d}$ at 20 ${ }^{\circ} \mathrm{C}$ (storage regime 1 ) than forced-air cooled, unwrapped fruit (Table 1 ). This indicates that hydrocooled, wrapped fruit had lighter color, were more reddish orange than red (the former being more typical of fresh strawberry color), and had more intense color than unwrapped fruit. Fruit from storage regime $2\left(7 \mathrm{~d}\right.$ at $1{ }^{\circ} \mathrm{C}+5 \mathrm{~d}$ at $15^{\circ} \mathrm{C}+$ $2 \mathrm{~d}$ at $7^{\circ} \mathrm{C}+1 \mathrm{~d}$ at $20^{\circ} \mathrm{C}$ ) in that trial did not show differences in $\mathrm{L}$ or hue angle for wrapped versus unwrapped hydrocooled fruit, but wrapped fruit had higher chroma.

In the second trial (Table 2), hydrocooling reduced the hue angle of unwrapped fruit in storage regime 1 $\left(7 \mathrm{~d}\right.$ at $1^{\circ} \mathrm{C}$ followed by $\mathrm{l} \mathrm{d}$ at $\left.20^{\circ} \mathrm{C}\right)$, but had the opposite effect in storage regime $3\left(7 \mathrm{~d}\right.$ at $1^{\circ} \mathrm{C}+7 \mathrm{~d}$ at $7{ }^{\circ} \mathrm{C}+$ $\mathrm{l} \mathrm{d}$ at $20^{\circ} \mathrm{C}$ ). Hydrocooling increased the chroma of wrapped fruit in storage regime 1 and wrapping retained higher $L^{*}$ in hydrocooled fruit in storage regime 1 and in fruit from both cooling methods in storage regime 3 . Forced-air cooled fruit had significantly higher hue angle after storage regime 1 when unwrapped, but the opposite was true after storage regime 3 . Storage time significantly reduced $\mathrm{L}^{*}$, hue, and chroma in trial 2 , indicating that the strawberries turned a darker red during storage. The interaction of wrapping and cooling method was nonsignificant for chroma, but was significant for $\mathrm{L}^{*}$ and hue angle.

In the third trial, wrapped fruit had higher $\mathrm{L}^{*}$ and chroma values (lighter and brighter) than unwrapped fruit (Table 3). There was no significant effect of wrapping on hue angle. In this trial, unwrapped, hydrocooled fruit were darker than wrapped, hydro- 
Table 1. Epidermal color, firmness, soluble solids content, total titratable acidity, and $\mathrm{pH}$ of 'Sweet Charlie' strawberry fruit after 8- or 15-d storage regimes as by affected by cooling methods and wrapping baskets with plastic film (Trial 1).

\begin{tabular}{|c|c|c|c|c|c|c|c|}
\hline Treatments & $\mathrm{L}^{*}$ value & Hue & Chroma & $\begin{array}{c}\text { Firmness } \\
(\mathrm{N})^{\mathrm{z}}\end{array}$ & $\begin{array}{c}\text { Soluble } \\
\text { solids } \\
\text { content } \\
(\%) \\
\end{array}$ & $\begin{array}{c}\text { Total } \\
\text { titratable } \\
\text { acidity } \\
(\%)\end{array}$ & $\mathrm{pH}$ \\
\hline \multicolumn{8}{|l|}{ Storage regime $\mathrm{l}^{\mathrm{y}}$} \\
\hline $\mathrm{HC} /$ unwrapped $^{\mathrm{x}}$ & 36.63 & 26.68 & 41.30 & 9.61 & 8.95 & 0.85 & 3.52 \\
\hline $\mathrm{HC} /$ wrapped & 37.95 & 27.59 & 43.35 & 11.13 & 8.11 & 0.79 & 3.48 \\
\hline FA/unwrapped & 34.67 & 23.77 & 38.61 & 4.80 & 10.55 & 0.91 & 3.56 \\
\hline \multicolumn{8}{|l|}{ Storage regime $2^{y}$} \\
\hline $\mathrm{HC} /$ unwrapped & 44.12 & 27.54 & 41.39 & 6.18 & 9.75 & 0.96 & 3.59 \\
\hline $\mathrm{HC} /$ wrapped & 38.07 & 27.02 & 44.17 & 9.17 & 7.66 & 0.79 & 3.55 \\
\hline FA/unwrapped & $\mathrm{NA}^{\mathrm{v}}$ & NA & NA & $\mathrm{NA}$ & NA & NA & NA \\
\hline FA/wrapped & NA & NA & NA & NA & NA & NA & NA \\
\hline Time & NS & NS & NS & $* * * *$ & NS & $* *$ & $* *$ \\
\hline Cooling method $\times$ wrap & NS & NS & NS & * & NS & NS & NS \\
\hline Cooling method $\times$ time & NS & NS & NS & * & NS & NS & NS \\
\hline Wrap $\times$ time & NS & * & NS & * & * & * & NS \\
\hline Cooling method $\times$ wrap $\times$ time & NS & NS & NS & NS & NS & NS & NS \\
\hline
\end{tabular}

cooled fruit and forced-air cooled fruit. Unwrapped, forced-air cooled fruit had higher chroma than unwrapped, hydrocooled fruit. Forced-air cooled fruit also tended to have higher $L^{*}$ and hue angle than hydrocooled fruit.

FIrmness. Wrapped fruit were significantly firmer than unwrapped fruit for all storage regimes in all three trials (Tables 1, 2, and 3). Hydrocooled fruit were firmer than forced-air cooled fruit only in the first trial (Table l). Hydrocooled, wrapped fruit were firmer than hydrocooled, unwrapped fruit for both storage regimes in trial 1 . In trial 2 (Table 2), after $7 \mathrm{~d}$ at $1{ }^{\circ} \mathrm{C}$ plus $\mathrm{l}$ d at $20^{\circ} \mathrm{C}$, wrapped fruit were firmer than the unwrapped fruit for all cooling methods. After storage regime 3 in the second trial, hydrocooled, unwrapped fruit were significantly softer than the other treatments. In trial 3 (Table $3)$, hydrocooled, wrapped fruit were significantly firmer than hydrocooled, unwrapped fruit, and forced-air cooled fruit were significantly firmer than hydrocooled fruit.

AsCORBIC ACID CONTENT, SOLUBLE SOLIDS CONTENT, TOTAL TITRATABLE ACIDITY, AND PH. Ascorbic acid showed no differences related to cooling method or wrapping in any of the three trial (data not shown). Unwrapped fruit from both storage regimes in the first trial retained higher SSC and TTA than the corresponding wrapped treatments, and fruit cooled by forced-air lost more weight than hydrocooled fruit (Table 1). Similar results were found for the second trial: forced air cooled, unwrapped fruit had the highest SSC and TTA for both storage regimes 1 and 3 (Table $2)$. The results of the third trial were similar to the previous two trials in that unwrapped fruit had higher SSC than wrapped fruit after storage, but for TTA the same was true only for hydrocooled fruit; and cooling method did not affect the SSC in trial 3, although forced-air cooled fruit did have higher TTA than hydrocooled fruit (Table 3). There was little effect of wrapping and cooling methods on $\mathrm{pH}$ in trials 1 and 2 (Tables 1 and 2). Wrapping strawberry baskets in PVC film also did not affect $\mathrm{pH}$ in trial 3 , however, in this trial hydrocooled fruit had higher $\mathrm{pH}$ than forced-air fruit (Table 3). The higher SSC and TTA levels in unwrapped and forced-air cooled fruit compared with wrapped and hydrocooled fruit is most likely related to greater water loss in the former treatments. Treatments that showed high SSC and TTA also had high percent weight loss (see below), which probably concentrated the sugars and acids in the fruit tissue.

Weight Loss. On the day after hydrocooling $\left(\mathrm{l} \mathrm{d}\right.$ at $\left.\mathrm{l}^{\circ} \mathrm{C}\right)$, strawberry fruit weighed from $0.66 \%$ to $1.3 \%$ more than their weight before hydrocooling. After 1 week of storage at $1{ }^{\circ} \mathrm{C}$ and also after an additional day at $20^{\circ} \mathrm{C}$ in all three trials, fruit wrapped with PVC film had much lower weight loss compared with unwrapped fruit (Table 4). Measurements after $7 \mathrm{~d}$ at $1{ }^{\circ} \mathrm{C}$ plus $1 \mathrm{~d}$ at $20^{\circ} \mathrm{C}$ showed that weight loss was also significantly lower for hydrocooled, wrapped fruit than for forced-air cooled, wrapped fruit in all three trials. However, without PVC wrap the advantage of hydrocooling over forced-air cooling in reducing weight loss was lost. Similar results were found for the longer duration, higher temperature storage regimes $2(7 \mathrm{~d}$ at $1{ }^{\circ} \mathrm{C}$, followed by $5 \mathrm{~d}$ at $15^{\circ} \mathrm{C}, 2 \mathrm{~d}$ at $7^{\circ} \mathrm{C}$, and $\mathrm{ld}$ at $\left.20^{\circ} \mathrm{C}\right)$ and $3(7 \mathrm{~d}$ at $\mathrm{l}$ 
Table 2. Epidermal color, firmness, soluble solids content, total titratable acidity, and $\mathrm{pH}$ of 'Sweet Charlie' strawberry fruit after 8- or 15-d storage regimes as affected by cooling methods and wrapping baskets with plastic film (Trial 2).

\begin{tabular}{|c|c|c|c|c|c|c|c|}
\hline Treatments & $\mathrm{L}^{*}$ value & Hue & Chroma & $\begin{array}{l}\text { Firmness } \\
(\mathrm{N})^{\mathrm{z}}\end{array}$ & $\begin{array}{c}\text { Soluble } \\
\text { solids } \\
\text { content } \\
(\%)\end{array}$ & $\begin{array}{c}\text { Total } \\
\text { titratable } \\
\text { acidity } \\
(\%)\end{array}$ & $\mathrm{pH}$ \\
\hline \multicolumn{8}{|l|}{ Storage regime $1^{y}$} \\
\hline $\mathrm{HC} /$ unwrapped $^{\mathrm{x}}$ & 35.31 & 25.64 & 35.74 & 7.01 & 7.57 & 0.80 & 3.56 \\
\hline $\mathrm{HC} /$ wrapped & 36.65 & 26.37 & 37.73 & 8.92 & 6.72 & 0.72 & 3.52 \\
\hline FA/unwrapped ${ }^{x}$ & 35.61 & 27.44 & 34.39 & 7.85 & 7.77 & 0.82 & 3.53 \\
\hline \multicolumn{8}{|l|}{ Storage regime $3^{y}$} \\
\hline HC/unwrapped & 33.29 & 24.61 & 32.62 & 6.43 & 7.31 & 0.70 & 3.71 \\
\hline $\mathrm{HC} /$ wrapped & 34.70 & 25.07 & 36.61 & 7.70 & 5.77 & 0.59 & 3.70 \\
\hline FA/unwrapped & 33.13 & 24.78 & 32.01 & 7.16 & 7.32 & 0.73 & 3.74 \\
\hline FA/wrapped & 36.29 & 27.36 & 37.50 & 7.65 & 6.37 & 0.65 & 3.71 \\
\hline Time & $* * * *$ & ** & $* * * *$ & ** & ** & ** & ** \\
\hline Cooling method $\times$ wrap & * & * & NS & * & NS & NS & NS \\
\hline Cooling method $\times$ time & ** & ** & ** & NS & NS & NS & NS \\
\hline Wrap $\times$ time & ** & * & $* * * *$ & NS & * & NS & NS \\
\hline Cooling method $\times$ wrap $\times$ time & $* * * *$ & ** & ** & NS & NS & NS & * \\
\hline
\end{tabular}

${ }^{\mathrm{z}} \mathrm{l} \mathrm{N}=0.2248 \mathrm{lbf}$.

yStorage regime $\mathrm{l}=7 \mathrm{~d}$ at $1{ }^{\circ} \mathrm{C}$, followed by $\mathrm{ld}$ at $20^{\circ} \mathrm{C}$; storage regime $3=7 \mathrm{~d}$ at $1{ }^{\circ} \mathrm{C}$, followed by $7 \mathrm{~d}$ at $7{ }^{\circ} \mathrm{C}$ and $1 \mathrm{~d}$ at $20{ }^{\circ} \mathrm{C}$; $\left(1.8 \mathrm{x}{ }^{\circ} \mathrm{C}\right)+32={ }^{\circ} \mathrm{F}$.

${ }^{x} \mathrm{HC}=$ fruit hydrocooled in $1{ }^{\circ} \mathrm{C}$ water to a fruit pulp temperature of $4{ }^{\circ} \mathrm{C}$ (about $6 \mathrm{~min}$ ); $\mathrm{FA}=$ fruit forced-air cooled for $1 \mathrm{~h}$ in a $1{ }^{\circ} \mathrm{C}$ cold room and $90 \%$ relative humidity to a fruit pulp temperature of $4^{\circ} \mathrm{C}$; and wrapped = plastic mesh baskets containing 10 fruit entirely wrapped with polyvinylchloride film after cooling.

NS, ${ }^{*}, * *,{ }^{* * *}$ Nonsignificant or significant at $P \leq 0.05,0.01$, or 0.0001 , respectively, by $F$ test.

${ }^{\circ} \mathrm{C}$ plus 7 d at $7{ }^{\circ} \mathrm{C}$ plus $1 \mathrm{~d}$ at $20^{\circ} \mathrm{C}$ ) (data not shown), meaning that as the storage time and temperature increased there was a corresponding increase in weight loss in all treatments.

DECAY INCIDENCE AND SEVERITY. In the first trial, there was a low percentage of decay in the hydrocooled strawberries after storage regime 1 while for the longer duration, higher temperature storage regime 2 , decay was much more prevalent, and wrapping greatly increased the incidence but not the severity of the decay (Table 5). For both storage regimes in the second trial, the incidence and severity of decay were highest in wrapped, forced-air cooled fruit; hydrocooled strawberries actually had less decay than the corresponding forced-air cooled fruit in every case. Wrapped fruit stored for $7 \mathrm{~d}$ at $1^{\circ} \mathrm{C}$ plus $1 \mathrm{~d}$ at $20^{\circ} \mathrm{C}$ also had significantly higher decay incidence than unwrapped fruit. In contrast to trial 1 , decay severity was also higher in the wrapped strawberries in the second trial. There was again more decay after storage regime 2 , but the differences in decay between wrapped and unwrapped fruit were less than for the shorter storage regime 1 . In the third trial, little decay developed in storage regime 1 , and more in storage regime 2 , but there was no consistent relationship between cooling method and decay incidence or severity (Table 5).

\section{Discussion}

Hydrocooled, wrapped fruit generally showed the best overall color, the original color being retained for a longer period than with forced-air cooled fruit (Tables 1, 2 and 3). This agrees with Roa et al. (1977), who concluded that hydrocooled, wrapped fruit showed no difference in color from fresh fruit after a simulated shipping period and presented the best quality compared to non-forced air cooled fruit. Collins and Perkins-Veazie (1993) also reported that strawberries that were wrapped showed less change in red color than unwrapped fruit. The only instance in which fruit color of hydrocooled, wrapped strawberries was not lighter and brighter red after storage than that of force-air cooled, wrapped fruit, was in the third trial (Table 3 ) and, in that case there was no significant difference in the color of fruit from the two treatments. Fruit in trial 3 had a large amount of initial bruising caused by harvest and transport operations. During subsequent storage, there were watersoaked areas on the surfaces of the hydrocooled fruit. Forced-air cooled fruit did not have water on the fruit surfaces.

Wrapped fruit showed greater firmness retention independent of the cooling method (Tables 1, 2 and 3 ). Hydrocooled fruit were generally as firm as or firmer than forced-air cooled fruit. This could have been due to differences in water loss, in which case the forced-air cooled fruit became more flaccid, showing less resistance to applied force. There was also a typical decrease in firmness over storage time as the fruit ripened.

The use of hydrocooling and PVC film wrap helped maintain fruit weight during storage better than forced-air cooling and no wrapping (Table 4). This is in agreement with the findings of Collins and Perkins-Veazie (1993) in which polyethylene wrap reduced water loss in storage treatments of about 2 weeks at $1{ }^{\circ} \mathrm{C}$ or $5{ }^{\circ} \mathrm{C}$. It was also reported by Roa et al. (1977) that hydrocooled strawberries wrapped with a PVC film lost less weight compared with non-hydrocooled fruit. It was also shown here, as well as by Roa et al. (1977), that hydrocooled fruit had an initial weight gain, in 
Table 3. Epidermal color, firmness, soluble solids content, total titratable acidity, and $\mathbf{p H}$ of 'Sweet Charlie' strawberry fruit after an 8-d storage regime as affected by cooling methods and wrapping baskets with plastic film (Trial 3).

\begin{tabular}{|c|c|c|c|c|c|c|c|}
\hline Treatments & $\mathrm{L}^{*}$ value & Hue & Chroma & $\begin{array}{c}\text { Firmness } \\
(\mathrm{N})^{\mathrm{z}}\end{array}$ & $\begin{array}{c}\text { Soluble } \\
\text { solids } \\
\text { content } \\
(\%)\end{array}$ & $\begin{array}{c}\text { Total } \\
\text { titratable } \\
\text { acidity } \\
(\%)\end{array}$ & $\mathrm{pH}$ \\
\hline \multicolumn{8}{|l|}{ Storage regime $1^{\mathrm{y}}$} \\
\hline $\mathrm{HC} /$ unwrapped $^{\mathrm{x}}$ & 35.26 & 23.85 & 37.04 & 6.13 & 8.86 & 0.71 & 3.70 \\
\hline $\mathrm{HC} /$ wrapped & 36.25 & 24.22 & 40.22 & 6.86 & 15.15 & 0.64 & 3.76 \\
\hline FA/unwrapped ${ }^{x}$ & 36.28 & 25.21 & 38.97 & 7.15 & 8.97 & 0.78 & 3.62 \\
\hline \multicolumn{8}{|l|}{ Main effects and interactions } \\
\hline Cooling method & * & * & NS & NS & NS & $\star * * *$ & * \\
\hline Wrap & ** & NS & $* * * *$ & NS & $*$ & * & NS \\
\hline Cooling method $\times$ wrap & NS & NS & NS & NS & NS & NS & NS \\
\hline
\end{tabular}

${ }^{2} 1 \mathrm{~N}=0.2248 \mathrm{lbf}$.

${ }^{y}$ Storage regime of $7 \mathrm{~d}$ at $\mathrm{I}^{\circ} \mathrm{C}$ followed by $\mathrm{l} \mathrm{d}$ at $20^{\circ} \mathrm{C}$. The extent of decay present at the end of storage regime $3\left(7 \mathrm{~d}\right.$ at $\mathrm{l}^{\circ} \mathrm{C}$, followed by $7 \mathrm{~d}$ at $7{ }^{\circ} \mathrm{C}$ plus $1 \mathrm{~d}$ at $\left.20{ }^{\circ} \mathrm{C}\right)$ in this trial precluded conducting color, firmness, weight loss or composition measurements; $\left(1.8 \times{ }^{\circ} \mathrm{C}\right)+32={ }^{\circ} \mathrm{F}$.

${ }^{x} \mathrm{HC}=$ fruit hydrocooled in $1{ }^{\circ} \mathrm{C}$ water to a fruit pulp temperature of $4{ }^{\circ} \mathrm{C}$ (about $6 \mathrm{~min}$ ); $\mathrm{FA}=$ fruit forced-air cooled for $1 \mathrm{~h}$ in a $1{ }^{\circ} \mathrm{C}$ cold room and $90 \%$ relative humidity to a fruit pulp temperature of $4{ }^{\circ} \mathrm{C}$; and wrapped = plastic mesh baskets containing 10 fruit entirely wrapped with polyvinylchloride film after cooling.

NS, ${ }^{*},{ }^{* *},{ }^{* * *}$ Nonsignificant or significant at $P \leq 0.05,0.01$, or 0.0001 , respectively, by $F$ test.

Table 4. Cumulative weight loss of 'Sweet Charlie' strawberry from storage regime 1 in three trials.

\begin{tabular}{|c|c|c|c|c|c|c|}
\hline \multirow[b]{2}{*}{ Treatments } & \multicolumn{2}{|c|}{ Trial 1} & \multicolumn{2}{|c|}{ Trial 2} & \multicolumn{2}{|c|}{ Trial 3} \\
\hline & $7 \mathrm{~d}$ at $1^{\circ} \mathbf{C}^{\mathrm{z}}$ & $+1 \mathrm{~d}$ at $20^{\circ} \mathrm{C}$ & $7 \mathrm{~d}$ at $1^{\circ} \mathrm{C}$ & $+1 \mathrm{~d}$ at $20^{\circ} \mathrm{C}$ & $7 \mathrm{~d}$ at $1^{\circ} \mathrm{C}$ & $+1 \mathrm{~d}$ at $20^{\circ} \mathrm{C}$ \\
\hline Storage regime $1^{\mathrm{z}}$ & & & & & & \\
\hline HC/unwrapped ${ }^{y}$ & 4.80 & 8.58 & 8.02 & 11.61 & 11.28 & 15.66 \\
\hline $\mathrm{HC} /$ wrapped & -0.57 & 0.17 & 0.37 & 1.41 & 4.26 & 5.45 \\
\hline FA/unwrappedy & $\mathrm{NA}^{\mathrm{x}}$ & 15.91 & 8.56 & 12.46 & 11.67 & 16.50 \\
\hline FA/wrapped & NA & 3.10 & 4.06 & 5.05 & 7.36 & 8.09 \\
\hline Cooling method & NS & $* * * *$ & $* * * *$ & $* * * *$ & * & * \\
\hline Wrap & $* * * *$ & $* * * *$ & $* * * *$ & $* * * *$ & $* * * *$ & $* * * *$ \\
\hline Cooling method $\times$ wrap & * & $* * * *$ & $\star * * *$ & $* * * *$ & * & NS \\
\hline
\end{tabular}

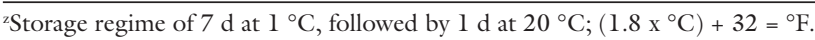

y $\mathrm{HC}=$ fruit hydrocooled in $1{ }^{\circ} \mathrm{C}$ water to a fruit pulp temperature of $4{ }^{\circ} \mathrm{C}$ (about $6 \mathrm{~min}$ ); $\mathrm{FA}=$ fruit forced-air cooled for $1 \mathrm{~h}$ in a $1{ }^{\circ} \mathrm{C}$ cold room and $90 \%$ relative humidity to a fruit pulp temperature of $4{ }^{\circ} \mathrm{C}$; and wrapped = plastic mesh baskets containing 10 fruit entirely wrapped with polyvinylchloride film after cooling.

${ }^{x}$ Not applicable; forced-air cooled fruit were discarded prior to completion of storage regime 2 in Trial 1 due to decay.

Ns, ${ }^{*}{ }^{* * * *}$ Nonsignificant or significant at $P \leq 0.05$ or 0.0001 , respectively, by $F$ test.

contrast to forced-air cooled fruit, which lose weight during cooling. Rose and Gorman (1936) reported that washed strawberries showed a gain in weight when compared to air-cooled fruit. Goble and Cooler (1962) reported that hydrocooled strawberries had small weight loss or some weight gain.

Soluble solids content, TTA, and $\mathrm{pH}$ were higher in unwrapped and forced-air treatments than in wrapped and hydrocooled treatments (Tables 1 , 2 , and 3 ). This was probably related to a concentrating effect from dehydration, since the former treatments favored high weight loss (Table 4). There were also apparently increases in SSC, TTA and pH over time. We found no effect of cooling method or wrapping on AAC, which is somewhat surprising since we have previously shown that treatments that enhance water loss tend to favor ascorbic acid degradation in strawberry fruit (Nunes et al., 1998).

In comparing hydrocooling and forced-air cooling, there was no clear indication that hydrocooling favored decay development in strawberry as has been widely assumed. Wrapping was more often associated with increased decay - in most cases wrapped fruit had higher incidence and severity of decay than unwrapped fruit, especially after the longer duration, higher temperature storage regimes. There was little or no development of decay in storage regime 1 after $7 \mathrm{~d}$ at $1^{\circ} \mathrm{C}$ plus $1 \mathrm{~d}$ at $20^{\circ} \mathrm{C}$ in all three trials (Table 5 ) with none, or just one, two, or three fruit out of 40 in a replicate affected by de- cay, and the severity amounting to less than $1 \%$ of the fruit surface affected by decay. These represent small amounts of decay, but it must be pointed out that the U.S. Standards for Grades of Strawberries (U.S. Department of Agriculture, 2006) allow no more than 2 or $3 \%$ decay for the U.S. No. 1 and U.S. No. 2 grades, respectively.

For the longer storage regimes 2 and $3\left(7 \mathrm{~d}\right.$ at $1^{\circ} \mathrm{C}$, followed by $5 \mathrm{~d}$ at $15^{\circ} \mathrm{C}, 2 \mathrm{~d}$ at $7^{\circ} \mathrm{C}$, and $1 \mathrm{~d}$ at $20^{\circ} \mathrm{C}$, and $7 \mathrm{~d}$ at $1{ }^{\circ} \mathrm{C}$, followed by $7 \mathrm{~d}$ at $7{ }^{\circ} \mathrm{C}$, and $\mathrm{l} \mathrm{d}$ at $20^{\circ} \mathrm{C}$, respectively) in the second and third trials, decay incidence and severity were much higher than for the shorter storage regime, but hydrocooled strawberries developed less decay than forced-air cooled fruit in trial 2 and forced-air cooled fruit developed less decay in 
Table 5. Incidence and severity of decay on 'Sweet Charlie' strawberry fruit after 8- or 15-d storage regimes in three trials as affected by cooling methods, addition of chlorine to hydrocooler water, and wrapping baskets with plastic film.

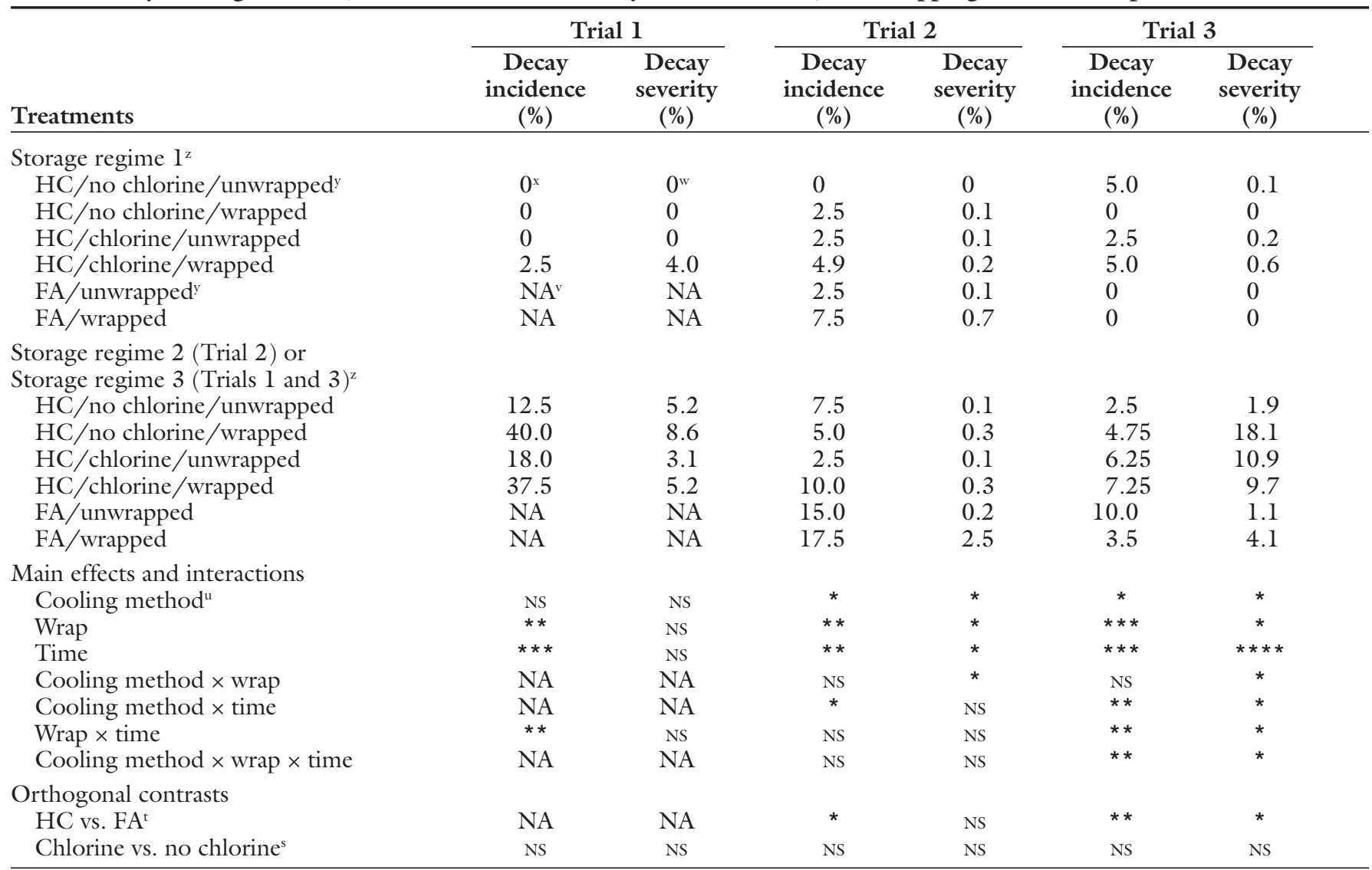

${ }^{2}$ Storage regime $\mathrm{l}=7 \mathrm{~d}$ at $1{ }^{\circ} \mathrm{C}$, followed by $1 \mathrm{~d}$ at $20^{\circ} \mathrm{C}$; storage regime $2=7 \mathrm{~d}$ at $1{ }^{\circ} \mathrm{C}$, followed by $5 \mathrm{~d}$ at $15{ }^{\circ} \mathrm{C}$ and $2 \mathrm{~d}$ at $7{ }^{\circ} \mathrm{C}$ plus $1 \mathrm{~d}$ at $20^{\circ} \mathrm{C}$; storage regime $3=7$ d at $l^{\circ} \mathrm{C}$, followed by $7 \mathrm{~d}$ at $7{ }^{\circ} \mathrm{C}$ plus $1 \mathrm{~d}$ at $20^{\circ} \mathrm{C} ;\left(1.8 \times{ }^{\circ} \mathrm{C}\right)+32={ }^{\circ} \mathrm{F}$.

${ }^{y} \mathrm{HC}=$ fruit hydrocooled in $1{ }^{\circ} \mathrm{C}$ water to a fruit pulp temperature of $4{ }^{\circ} \mathrm{C}$ (about $6 \mathrm{~min}$ ); chlorine $=200 \mathrm{mg} \cdot \mathrm{L}^{-1}$ free chlorine added to hydrocooling water and the $\mathrm{pH}$ adjusted $\mathrm{pH} 7 ; \mathrm{FA}=$ fruit forced-air cooled for $1 \mathrm{~h} \mathrm{in} \mathrm{a} 1{ }^{\circ} \mathrm{C}$ cold room and $90 \%$ relative humidity to a fruit pulp temperature of $4{ }^{\circ} \mathrm{C}$; and wrapped $=$ plastic mesh baskets containing 10 fruit entirely wrapped with polyvinylchloride film after cooling.

${ }^{x}$ Mean percentage of fruit showing decay symptoms in four replicate sets of 40 fruit.

"Mean percentage of individual fruit surface area affected by decay converted from the midpoint of the Horsfall-Barrat categories for four replicate sets of 40 fruit; the Horsfall-Barrat rating scale was as follows: $1=0 \%$ to $1 \% ; 2=1 \%$ to $3 \% ; 3=3 \%$ to $6 \% ; 4=6 \%$ to $12 \% ; 5=12 \%$ to $25 \% ; 7=50 \%$ to $75 \% ; 8=75 \%$ to $88 \% ; 9=88 \%$ to $94 \% ; 10$ $=94 \%$ to $97 \% ; 11=97 \%$ to $99 \% ; 12=99 \%$ to $100 \%$.

"Not applicable - forced-air cooled fruit were discarded prior to completion of storage regime 2 in Trial 1 due to decay.

"Trial $1=$ hydrocooled with or without chlorine in water. Trials 2 and $3=$ hydrocooled with chlorine, hydrocooled without chlorine, and forced-air cooled

${ }^{t}$ Mean incidence or severity of decay among hydrocooled compared with forced-air cooled fruit.

${ }^{s}$ Mean incidence or severity of decay among fruit that were hydrocooled with chlorinated water compared with fruit that were hydrocooled using water containing no chlorine. NS, ${ }^{* * *}, * * *, * * *$ Nonsignificant or significant at $P \leq 0.05,0.01,0.001$, or 0.0001 , respectively, by $F$ test.

trial 3 (Table 5). The highest measured decay incidence in this study was in the hydrocooled fruit from the first trial that were subjected to storage regime 2 , but the forced-air cooled fruit had been discarded before the end of that storage period due to excessive decay. In the third trial, there was excessive harvest injury and consequently relatively severe decay, but there was still not a clear relationship between cooling method and incidence of decay.

Gooding (1976) reported that susceptibility to Botrytis cinerea in strawberry increased in fruit that were previously bruised. We observed in the third trial that the hydrocooled fruit accumulated water at the bruise sites as indicated by a watersoaked appearance, which would be expected to favor decay lesion establishment in the hydrocooled fruit, but decay incidence was not greatly affected. Forced-air cooled fruit, however, did develop less severe decays than most of the hydrocooling treatments in the third trial. The above discussion agrees with the findings of Rose and Gorman (1936) that wetting strawberries in and of itself does not increase decay. Goble and Cooler (1962) also reported that hydrocooled strawberries had less decay compared to non-hydrocooled fruit. Nevertheless, minimizing extra handling of the fruit in order to avoid additional bruising would be an important consideration in applying hydrocooling in commercial strawberry handling operations. Use of returnable plastic containers to hold the strawberry baskets or clamshells would allow hydrocooling to be performed with no additional handling compared with current forced-air cooling operations.

\section{Conclusion}

Hydrocooling reduced the pulp temperature of strawberry fruit in about one-tenth the time required for forced-air cooling. Hydrocooled strawberry fruit wrapped with PVC film retained better color quality after storage than forced-air cooled fruit. Hydrocooled, wrapped fruit also exhibited less darkening during storage and retained a more typical and intense reddish orange hue than unwrapped fruit. 
Hydrocooled, wrapped fruit lost less weight and maintained equal or greater firmness during storage compared with forced-air cooled strawberries; without wrapping, the advantage of hydrocooling over forced-air cooling in reducing weight loss was eventually lost during prolonged storage. Cooling treatment had no consistent effect on incidence and severity of decay and chlorine treatment of the hydrocooling water had no effect on any of the quality factors measured and was not consistently effective in decreasing disease. There were no differences in ascorbic acid content between wrapped and unwrapped fruit or forced-air cooled and hydrocooled fruit. Soluble solids content, TTA, and $\mathrm{pH}$ were higher for unwrapped and forced-air treatments due to increased water loss. It appears that, if properly managed, hydrocooling could be successfully used to rapidly precool strawberries with potentially better quality retention and without increasing decay.

\section{Literature cited}

Arifin, B.B. and K.V. Chau. 1987. Forcedair cooling of strawberries. ASAE Paper 87-6004. Amer. Soc. Agr. Eng., St. Joseph, Mich.

Bennet, A.H., R.E. Smith, and J.C. Fortson. 1965. Hydrocooling peaches. Practical guide for determining cooling requirements and cooling times. Ga. Agr. Expt. Sta. Agr. Info. Bul. 293.

Collins, J.K. and P. Perkins-Veazie. 1993. Postharvest changes in strawberry fruit stored under simulated retail display conditions. J. Food Qual. 16:133-143.

Ferreira, M.D., J.A. Bartz, S.A. Sargent and J.K. Brecht. 1996. An assessment of the decay hazard associated with hydrocooling strawberries. Plant Dis. 80:1117-1122.

Goble, W.E. and F.W. Cooler. 1962. Quality and consumer acceptance of hydrocooled strawberries. Tenn. Agr. Expt. Sta. Bul. 344.
Gooding, H.J. 1976. Resistance to mechanical injury and assessment of shelf life in fruit of strawberry (Fragaria ananassa). Hort. Res. 16:71-82.

Hardenburg, R.E., A.E. Watada, and C.Y. Wang. 1986. The commercial storage of fruits, vegetables, and florist and nursery stocks. Agr. Hdbk. No. 66. U.S. Dept. Agr., Washington, D.C.

Hochberg, Y. and A.C. Tamhane, 1987. Multiple comparison procedures. Wiley, New York.

Horsfall, J.G. and R.W. Barrat. 1945. An improved grading system for measuring plant diseases. Phytopathology 35:655. (Abstr.).

Kasmire, R.F. and J.F. Thompson. 1992. Cooling horticultural commodities: Selecting a cooling method, p. 63-68. In: A.A. Kader(ed.). Postharvest technology of horticultural crops. Publ. 3311. Univ. Calif., Div. Agr. Natural Resources, Berkeley.

Kays, S.J. 1991. Heat, heat transfer and cooling, p. 457-505. In: S.J. Kays (ed.). Postharvest physiology of perishable plant products. Van Nostrand, New York.

Lill, R.E. and G.F. Laundon. 1984. Chlorination of asparagus hydrocooling water for the control of post-harvest decay organisms. N.Z. J. Expt. Agr. 12:43-45.

McGuire, R.G. 1992. Reporting of objective color measurements. HortScience 27:1254-1255.

Mitcham, E.J. and F.G. Mitchell. 2002. Postharvest handling systems: Small fruits. II. Strawberries and cane berries, p. 364-370. In: A.A. Kader (ed.). Postharvest technology of horticultural crops. Publ. 3311. Univ. Calif., Div. Agr. Natural Resources, Berkeley.

Mitchell, F.G., E.J. Mitcham, J.F. Thompson, and N. Welch. 1996. Handling strawberries for fresh market. Publ. 2442. Univ. Calif., Div. Agr. Natural Resources, Berkeley.

Nunes, M.C.N., J.K. Brecht, A.M.M.B. Morais, and S.A. Sargent. 1995. Physical and chemical quality characteristics of strawberries after storage are reduced by a short delay to cooling. Postharvest Biol. Technol. 6:17-28.

Nunes, M.C.N., J.K. Brecht, A.M.M.B. Morais, and S.A. Sargent. 1998. Controlling temperature and water loss to maintain ascorbic acid levels in strawberries during postharvest handling. J. Food Sci. 63:1033-1036.

Redit, W.H., M.A. Smith, and P.L. Benfield. 1955. Tests on hydrocooling and refrigeration of peaches in transit from Georgia and South Carolina, 1954. U.S. Dept. Agr., Agr. Mktg. Serv. AMS-62.

Roa, R.D., J.H. di Pendima, and D.R. Guemes. 1977. The technical feasibility of export of fresh strawberries to Germany by air. Revista del Instituto de Tecnologia de Alimentos. 2:79-88.

Rose, D.H. and E.A. Gorman. 1936. Handling, cooling, and transportation of Florida strawberries. Fla. Agr. Expt. Sta. Tech. Bul. 525.

Sargent, S.A., M.T. Talbot, and J.K. Brecht. 1991. Evaluating cooling methods for vegetable packinghouse operations. Fla. Coop. Ext. Serv. Publ. SSVEC47.

Shewfelt, R.L., C.N. Thai, and J.W. Davis. 1988. Prediction of changes in color of tomatoes during ripening at different constant temperatures. J. Food Sci. 53:1433-1437.

Talbot, M.T. and K.V. Chau. 1991. Precooling strawberries. Fla. Coop. Ext. Serv. Circ. CIR942.

Terada, M., Y. Watanabe, M. Kunitomo, and E. Hayashi. 1978. Differential rapid analysis of ascorbic acid 2 -sulfate by dinitrophenylhydrazine method. Anal. Biochem. 84:604-608.

Thompson, J.F., F.G. Mitchell, T.R. Rumsey, R.F. Kasmire, and C.H. Crisosto. 2002. Commercial cooling of fruits, vegetables and flowers. Publ. 21567. Univ. Calif., Div. Agr. Natural Resources, Berkeley.

U.S. Department of Agriculture. 2006. United States standards for grades of strawberries. U.S. Dept. Agr., Agr. Mktg. Serv., Washington, D.C. 